\title{
PENDEKATAN PENDIDIKAN MULTIKULTURAL SEBAGAI RESOLUSI KONFLIK DI INDONESIA
}

\author{
Irsyaadul 'Ibaad ${ }^{1 *}$, Fita Triyana ${ }^{2}$ and Rachmad Sukriyanto ${ }^{3}$ \\ ${ }^{1}$ Universitas Ahmad Dahlan Yogyakarta \\ ${ }^{2}$ Universitas Ahmad Dahlan Yogyakarta \\ ${ }^{3}$ Universitas Ahmad Dahlan Yogyakarta \\ 1irsyaadul1811331037@,webmail.uad.ac.id \\ ${ }^{2}$ fita1811331042@webmail.uad.ac.id \\ 3․
}

\section{ARTICLE INFO}

\section{Article history}

Received January 10, 2022

Revisied January 17, 2022

Accepted January 19, 2022

Keywords:Education, multicultural,conflict resolution

Kata Kunci: Pendidikan, multikultural,resolusi konflik

\begin{abstract}
Indonesia is a very large country with cultural diversity from east to west. The right intermediary or media to communicate learning in the form of Pancasila values and the principles of state and nation life is education, especially multicultural education. The purpose of this research is to find out which approach to multicultural education is suitable to be applied in Indonesia. This research uses a qualitative approach with library research, but the data analysis method used is content analysis. Multicultural education can be defined as cultural diversity education that responds to demographic and cultural changes within a particular community or the world as a whole. There are many types of multicultural conflicts in Indonesia: individual conflicts, social conflicts, racial conflicts, religious conflicts, family conflicts, and cultural conflicts. Other ways to resolve disputes include: the victory of one party over another, compromise between the warring parties, reconciliation between the warring parties, forgiving the other party from one side, conflict-free agreements. Multicultural education in Indonesia is more appropriate and suitable to be used as an educational approach. To implement multicultural education, several approaches can be used in the implementation process, namely the contribution approach, additive approach, transformation approach, and social action approach. This approach is applied by integrating the values of multicultural education in learning materials and in school culture.
\end{abstract}

\begin{abstract}
ABSTRAK
Indonesia adalah negara yang sangat besar dengan keragaman budaya dari timur ke barat. Perantara atau media yang tepat untuk mengkomunikasikan pembelajaran berupa nilai-nilai Pancasila dan prinsip-prinsip kehidupan bernegara dan berbangsa adalah pendidikan, khususnya pendidikan multikultural. Tujuan dari penelitian ini adalah untuk mengetahui pendekatan pendidikan multikultural yanng cocok untuk diterapkan di Indonesia. Penelitian ini menggunakan pendekatan kualitatif dengan metode library research (studi pustaka), namun metode analisis data yang digunakan adalah analisis isi atau content analysis. Pendidikan multikultural dapat didefinisikan sebagai pendidikan keragaman budaya yang merespon perubahan demografis dan budaya dalam komunitas tertentu atau dunia secara keseluruhan. Ada banyak jenis konflik multikultural di Indonesia: konflik individu, konflik sosial, konflik ras, konflik agama, konflik keluarga, dan konflik budaya. Cara lain untuk menyelesaikan perselisihan antara lain: kemenangan satu pihak atas pihak lain, kompromi antara pihak-pihak yang berperang, rekonsiliasi antara pihak-pihak yang berperang, saling memaafkan pihak lain dari satu pihak, kesepakatan bebas konflik.Pendidikan multikultural di Indonesia lebih tepat dan cocok digunakan menjadi pendekatan yaitu pendekatan pendidikan. Untuk mengimplementasi pendidikan multikultural dapat menggunakan beberapa pendekatan dalam proses penyelenggaraannya, yaitu pendekatan kontribusi, pendekatan aditif, pendekatan transformasi, dan pendekatan aksi sosial. Pendekatan tersebut diterapkan dengan cara mengintegrasikan nilainilai pendidikan multikultural dalam materi pembelajaran dan dalam kultur budaya sekolah.
\end{abstract}




\section{PENDAHULUAN}

Masyarakat Indonesia yang majemuk dapat dinilai dari setidaknya dua karakteristik unik yang dicirikan oleh adanya kesatuan-kesatuan sosial berdasarkan perbedaan suku, agama, adat dan daerah, dan yang lainnya vertikal. Hal ini ditandai dengan perbedaan vertikal yang jelas antara lapisan atas dan bawah. Ini sangat penting (Nasikun, 2007). Dengan membentang nya luas Indonesia dari timur ke barat Maka sangat beragam juga budaya-budaya di berbagai wilayah di Indonesia. Indonesia memiliki banyak sekali pulau, maka dari itu sudah sewajarnya jika antar pulau memiliki perbedaan dari segi aspek budaya dan beberapa hal lainnya.

Perserikatan Bangsa-Bangsa telah menemukan bahwa hingga 75 konflik besar di dunia memiliki asal dan penyebab dalam aspek budaya (Zulkifli, 2020). Konflik yang berasal dari aspek budaya memang berpotensi besar menimbulkan konflik-konflik besar karena aspek budaya ya memiliki hal yang sakral yang dapat memunculkan konflik besar tersebut. Berdasarkan laporan tempo tahun 2016 dalam Zulkifli (2020) terdapat beberapa kasus besar yang terjadi di Indonesia yang berkaitan dengan konflik kultural diantaranya: Tragedi Sampit, tragedi ini terjadi akibat konflik antara masyarakat Dayak dan Madura di Sampit, Kalimantan Tengah. Diperkirakan korban tewas dalam konflik 10 hari itu mencapai 469 orang.

Konflik Maluku, konflik Maluku adalah konflik yang berlatar belakang agama, perselisihan kekerasan antara kelompok Muslim dan Kristen. Sekitar 8.000 hingga 9.000 orang tewas dalam konflik Maluku, lebih dari 29.000 rumah dibakar, 45 masjid, 47 gereja, 719 toko, 38 gedung pemerintah dan 4 bank hancur. Perselisihan ini paling lama, mencapai empat tahun.

Konflik 1998, krisis ekonomi menimbulkan konflik sosial di penghujung masa orde baru. Runtuhnya pemerintahan Suharto ditandai dengan merebaknya kecemasan di berbagai wilayah Indonesia. Sasaran utama konflik adalah milik orang Tionghoa. Mengingat peristiwa-peristiwa yang pernah dialami Indonesia di masa lalu, ini mungkin menjadi pelajaran yang harus dihindari di masa depan. Apalagi di Indonesia, kita bisa belajar dari masa lalu agar kejadian serupa tidak terulang di masa depan. Sesuai dengan perbedaan yang ada di Indonesia, prinsip bernegara dan kehidupan bernegara harus selalu didahulukan.

Pendidikan merupakan sarana penting dan media yang ampuh untuk mengajarkan norma, menyebarluaskan nilai-nilai dan menanamkan etos kerja di kalangan anggota masyarakat. Pendidikan juga dapat menjadi sarana peningkatan kepribadian bangsa, penguatan jati diri bangsa, dan penguatan jati diri bangsa. Pendidikan telah menjadi sarana strategis untuk membangun kesadaran kolektif sebagai warga negara dengan memperkuat ikatan sosial dan keutuhan bangsa dengan tetap menghormati keragaman budaya, ras, suku, dan agama. Bangsa Indonesia yang beriman dan bertakwa kepada Tuhan Yang Maha Esa, berakhlak mulia., Berkepribadian mandiri, tangguh, 
cerdas, kreatif, disiplin, etos kerja, profesional, bertanggung jawab, produktif, sehat jasmani dan rohani (Hasan \& Robiatul, 2017: 225).

Bhinneka Tunggal Ika harus senantiasa dibenamkan dalam semangat kehidupan berbangsa dan bernegara. Nilai persatuan dalam Sumpah Pemuda merupakan kekuatan besar dalam membangun nilai-nilai luhur yang terkandung dalam nasionalisme pengubah gaya hidup dan Pancasila bangsa Indonesia dalam kehidupan sehari-hari mereka. Untuk dapat mempelajari dalam bentuk nilai-nilai Pancasila dan prinsip-prinsip bernegara dan kehidupan berbangsa, diperlukan suatu perantara atau media yang dapat melakukan hal tersebut secara maksimal. Perantara atau media yang tepat dalam hal ini adalah pendidikan, khususnya pendidikan multikultural. Dari uraian di atas perihal pendidikan dan juga konflik multikultural yang pernah ada di indonesia, maka penelitian ini akan membahas terkait pendekatan pendidikan multikultural sebagai resolusi konflik di Indonesia.

\section{METODE PENELITIAN}

Penelitian ini menggunakan pendekatan kualitatif dengan metode library research (studi pustaka), adapun teknik analisis data yang digunakan adalah content analisis atau analisis isi. Analisa data dapat juga dilakukan melalui tahapan display data, reduksi data, verifikasi data dan kesimpulan. Menurut Sugiyono (2018) Penelitian kepustakaan merupakan kajian teoritis referensi serta literatur ilmiah lainnya yang berkaitan dengan budaya nilai dan norma yang berkembang pada situasi sosial yang diteliti. Sedangkan menurut Khatibah (2011) penelitian kepustakaan sebagai kegiatan yang dilakukan secara sistematis untuk mengumpulkan mengolah dan mengumpulkan data dengan menggunakan teknik tertentu guna mencari jawaban atas permasalahan yang dihadapi melalui penelitian kepustakaan.

Mirshad (2014) menyatakan bahwa dampak kegiatan pada penelitian kepustakaan meliputi: Pertama, Mencatat semua wawasan tentang masalah penelitian yang diperoleh dalam setiap percakapan penelitian dalam literatur dan sumber penemuan terbaru. Kedua, Mengintegrasikan semua pengetahuan, baik dalam teori maupun pengetahuan baru. Ketiga, Analisis semua penemuan dari bacaan yang berbeda terkait dengan kekurangan, kelebihan masing-masing sumber, atau hubungan antara setiap wacana yang dibahas di sana. Keempat, dengan menghadirkan pengetahuan baru dengan mengkritisi dan merangkum berbagai pemikiran tentang masalah pemikiran, memberikan ide-ide penting untuk temuan wacana sebelumnya. 


\section{HASIL DAN PEMBAHASAN}

\subsection{Pendidikan Multikultural}

Multikulturalisme adalah sebuah idealisme yang dapat menjadi alat atau sarana untuk mengangkat derajat kemanusiaan dan kemanusiaannya (Suparlan, 2002). Di sisi lain, menurut Reed (1997) dari Suparlan (2002), multikulturalisme adalah perwujudan masyarakat yang lebih besar di mana benda-benda mencakup semua budaya komunitas terkecil dan memiliki budaya waktu.

Selain itu, pendidikan multikultural adalah proses pengembangan potensi manusia seutuhnya, pluralisme, dan heterogenitas sebagai hasil dari penghormatan terhadap keragaman budaya, suku, suku, denominasi atau agama (Muzaki, 2018). Pendidikan multikultural merupakan gerakan dan proses pembaruan untuk menciptakan lingkungan pendidikan yang setara bagi peserta didik (Al Arifin, 2012). Dilingkungan pendidikan pendidikan multicultural merupakan sebagai salah satu kunci control siswa atau peserta didik dalam lingkungan sekolah. Jika siswa itu memahami keberagaman dan saling menghargai satu sama lain, maka akan tercipta lingkungan yang setara siswa.

Pendidikan multikultural adalah pendekatan pendidikan dan pembelajaran yang didasarkan pada nilai-nilai demokrasi dan mempromosikan pengembangan pluralisme budaya di hampir semua cara yang inklusif. Pendidikan multikultural adalah upaya untuk mengembangkan kurikulum yang mencapai kesetaraan pendidikan, mempromosikan pemahaman kelompok etnis, dan menekan praktik-praktik yang menindas. Pendidikan multikultural adalah reformasi sekolah yang komprehensif dan pendidikan dasar untuk semua siswa, menentang segala bentuk diskriminasi dan penindasan di kelas, dan hubungan interpersonal di dalam kelas, dan prinsip-prinsip demokrasi keadilan sosial (Ibrahin, 2013: 138). Secara sederhana, pendidikan multikultural dapat didefinisikan sebagai pendidikan keragaman budaya yang merespon perubahan demografis dan budaya pada suatu komunitas tertentu atau dunia secara keseluruhan (Ibrahim, 2013). Pendidikan multikultural mengajarkan untuk menghargai keragaman, apalagi keragaman yang sangat beragam di Indonesia ini dengan ras, suku, budaya, agama dan social yang berbeda beda.

Dalam dunia pendidikan apalagi di era milenial yang sekarang ini dikenal dengan istilah era 4.0, banyak sekali perubahan yang terjadi di dunia pendidikan yang ada di Indonesia ini. Salah satunya dalam pendidikan Islam yang bertujuan untuk menciptakan kaum muslim dan muslimat yang memiliki karakter mencerminkan generasi milenial melek akan pentingnya pendidikan yang berlandaskan agama, karena itu salah satu ciri khas seorang mukmin. Walaupun teknologi yang sudah merajalela di Indonesia generasi muda diharapkan mampu untuk memanfaatkan teknologi yang ada dengan baik dan digunakan sesuai dengan kebutuhan. 
Sudah saatnya kita sebagai generasi milenial mampu melakukan gerakan perubahan dalam dunia pendidikan yang ada di Indonesia, agar tercipta generasi penerus paham pentingnya pendidikan yang berlandaskan agama dan dapat memanfaatkan teknologi yang ada. Dan kita saling memberikan semangat terhadap saudara kita yang berbeda ras, suku, budaya, dan agama, agar tercipta generasi milenial Indonesia paham dan pentingnya pendidikan untuk bangsa kita Indonesia.

\subsection{Macam-macam Konflik Multikultural}

Ada beberapa macam konflik multikulturan yang ada di Indonesia:Konflik Individu, maksudnya adalah konflik yang terjadi adanya benturan dua keinginan yang menyebabkan perselisihan diantara keduanya. Akhirnya timbulnya konflik yang menyebabkan pertengkaran diantara keduanya. Hal ini terjadi karena setiap orang memiliki kebutuhan yang berbeda, dan kehendak yang harus terwujud, jadi jangan selalu apa-apa harus sama atau bahkan tidak boleh mementingkan kepentingan pribadi dan harus memilih kepentingan orang lain. Memaksakan kehendak berarti mematikan keinginan orang lain.

Konflik Antar Sosial, konflik ini biasa dikenal dengan konflik horizontal. Disebabkan karena berbenturan oleh dua kelompok yang memiliki kepentingan yang berbeda. ${ }^{1}$ Jadi konflik ini banyak terjadi dimana saja entah di di Indonesia bahkan diluar negeri. Karena kepentingan suatu kelompok memang berbeda-beda, tetapi alangkah baiknya saling menghormati dan saling bertoleran dalam hal ini. Supaya tidak terjadi konflik yang bisa menyebabkan perpecahan antara dua kelompok yang berbeda (Yustisia, 2015).

Konflik Rasial, konflik ini terjadi adanya dua ras yang berbeda mengenai suatu isu. ${ }^{2}$ Faktor penyebabnya adalah ketimpangan sosial ekonomi, konflik ini juga terjadi karena perbedaan warna kulit yang menyebabkan konflik bisa terjadi, bahkan mereka dapat seenaknya sendiri dengan membeda-bedakan ras masing-masing. Konflik ini banyak terjadi di amerika, antara kulit putih dan hitam.

Konflik Agama, konflik ini sering terjadi karena perbedaan paham atau perbedaan manhaj. Hal ini banyak sekali adanya perbandingan antara agama satu dengan yang lain. Bahkan kadangkadang membeda-bedakan antara agama yang satu dengan yang lain. Sebenarnya itu tidak diperbolehkan karena sudah memiliki keyakinan masing-masing. Salah satu agar terhindar dari konflik agama sebaiknya saling menghormati dan bertoleran terhadap sesama agama. Serta memahami makna toleransi yang sebenar-benarnya, bukan mencampur adukan agama. 
Konflik Keluarga, konflik ini terjadi karena faktor kecemburuan atau perekonomian. Karena adanya ketidak percayaan antara suami dan istri, adik dan kakak, atau sebaliknya. Konflik keluarga cenderung menimbulkan dampak yang berbahaya terhadap lingkungan keluarga yang lain, anak kehilangan orang tua bahkan sampai renggangnya hubungan kekeluargaan antar keluarga yang lain.

Konflik Budaya, konflik ini terjadi karena perbedaan budaya antara daerah yang satu dengan yang lain, yang menyebabkan saling menjelek-jelekan bahkan bisa jadi saling adu kebudayaan daerah masing-masing. Perbedaan paham kebudayaan ditambah paham keagamaan yang berbeda beda, juga yang banyak menjadi konflik di lingkungan masyarakat. Seperti tradisi yang masih dilestarikan di masyarakat jatilan, angguk, mitoni dan sebagainya. Ada yang masih menjaga tradisi tersebut dan ada yang sudah tidak memakai. Namun titik pentingnya adalah saling menghargai satu sama lain agar tidak terjadi konflik.

Perbedaan Pendirian, perbedaan pendapat seringkali menimbulkan konflik sosial. Dalam masyarakat, kita sering memiliki perbedaan pendapat dan pandangan tentang sesuatu, seperti sikap politik. Tidak jarang sikap politik yang berbeda menumbuhkan konflik sosial di masyarakat. Perbedaan keyakinan seringkali menimbulkan konflik sosial di masyarakat. Dewasa ini, masyarakat semakin menoleransi penggunaan cara-cara kekerasan dalam menegakkan prinsip-prinsip agama. Hal ini terjadi tidak hanya di kalangan pemeluk agama, tetapi juga dari pemeluk agama lain.

Perbedaan kebudayaan, perbedaan budaya antara budaya lokal dan non-daerah juga menjadi salah satu faktor penyebab terjadinya konflik sosial. Kepentingan yang Berbeda-Setiap orang memiliki minat yang berbeda. Perbedaan tersebut dapat menimbulkan konflik sosial. Demonstrasi sopir taksi tradisional yang berlangsung beberapa waktu lalu berakhir dengan kontroversi. Mereka menolak keberadaan taksi berbasis online yang dianggap sebagai sumber pendapatan. Perubahan Sosial-Konflik sosial dapat menyebabkan perubahan sosial dan sebaliknya (Dewantara, 2017).

Itu adalah macam-macam konflik yang sering terjadi di Indonesia. Dalam hal ini supaya meminimalisir terjadinya konflik multikultural seharusnya kita sebagai makhluk sosial untuk tidak saling menjatuhkan satu sama lain, menjelek-jelekkan atau memperdebatkan entah itu warna kulit, jenis rambut dan lain sebagainya. Karena itu hal yang sensitif didengar di sebagian kalangan orang. Jadi kita saling menghormati, mentoleransi sesama makhluk sosial yang tinggal di bumi pertiwi ini dengan damai, tentram dan saling memberikan semangat terhadap sesama untuk menjaga kebinekaan tunggal Ika Indonesia.

\subsection{Solusi Menghadapi Konflik Multikultural}

Dalam hal ini, konflik mau tidak mau muncul di masyarakat, terutama karena kita adalah orang-orang pekerja yang tidak bisa hidup sendiri tanpa bantuan dari luar atau makhluk sosial. Oleh karena itu, untuk mengekang dan mengatasi berbagai konflik yang dapat terjadi ketika bekerja di 
lingkungan multikultural atau multikultural, setiap orang mengembangkan kemampuan untuk bekerja dalam budaya yang berbeda dan menjadikan perbedaan ini sebagai entitas yang kuat dan intim. Secara umum, ada tiga jenis manajemen perselisihan sosial: arbitrase, mediasi, dan arbitrase (Keith, 1993).

Konsiliasi atau Arbitrase di sini diartikan sebagai suatu bentuk pengelolaan sengketa yang dilakukan oleh suatu badan tertentu untuk memungkinkan terjadinya diskusi dan pengambilan keputusan yang adil di antara para pihak yang bersengketa. Mediasi pengelolaan sengketa terjadi jika kedua pihak yang bersengketa sepakat untuk menunjuk pihak ketiga sebagai mediator. Pihak ketiga ini telah mengomentari solusi terbaik untuk kompetisi. Sehingga dalam penyelesaian konflik yang terjadi antara dua belah pihak di bantu oleh pihak ketiga yang bertindak sebagai mediator atas dasar persetujuan dua belah pihak.

Akhirnya, arbitrase biasanya terjadi ketika para pihak yang bersengketa setuju atau terpaksa menerima kehadiran pihak ketiga yang membuat keputusan terbaik untuk menyelesaikan sengketa tersebut. Dalam hal ini, banyak konflik yang dapat diselesaikan dengan baik tanpa adanya perkelahian atau kekerasan. Sebagai makhluk sosial yang tidak bisa lepas dari konflik multikultural seperti budaya, agama, dan ras, kita saling toleran terhadap makhluk sosial lainnya (Mangkunegara, 2005). Dalam realitanya manusia tidak bisa terlepas dari konflik dalam hidupnya, karena secara sederhana manusia memiliki akal masing-masing, ego yang besar, segala kecerdasannya, dan kehendak sendiri-sendiri. Sehingga memang benar jika dengan segala keberagamannya, manusia di perintahkan untuk saling mengenal, mengenak baik secara kahir maupun batin. Faktanya memang benar Manusia itu memiliki ego dan kehendak masing-masing maka dari itu ketika ego dan ganda tersebut tidak dapat terkendali maka akan memungkinkan terjadinya konflik konflik. Akan tetapi apabila manusia tersebut dapat mengendalikan ego dan kehendak maka akan menimalisir timbulnya konflik antar manusia. Karena memang ego tersebut sudah menjadi bawaan manusia maka ego tersebut dapat dihilangkan akan tetapi dapat dikendalikan oleh diri sendiri setiap manusia. Kemudian ketika menyelesaikan konflik maka tidak boleh mendahulukan ego karena pada akhirnya nanti akan sulit dan menemui penyelesaian yang cocok ketika setiap kedua belah pihak menurunkan ego mereka masing-masing.

Georg Simmel menyatakan bahwa ada cara lain untuk menyelesaikan konflik, yaitu: Pertama, kemenangan satu pihak atas pihak lain. Kedua, kompromi atau negosiasi antara pihakpihak yang berperang sehingga tidak ada pihak yang merasa kalah total. Negosiasi di Helsinki, Finlandia, misalnya, telah menyelesaikan persoalan GAM (Gerakan Aceh Merdeka) dengan Republik Indonesia. Dalam perundingan tersebut disepakati bahwa Nangro Achedal Salaam masih menjadi bagian dari Negara Kesatuan Republik Indonesia. Ketiga, rekonsiliasi antara pihak-pihak yang berseberangan. Ini mengembalikan rasa saling percaya antara pihak-pihak yang bersaing. 
Misalnya, dalam menyelesaikan konflik Indonesia-Malaysia atas Sipadan dan Rigitan. Keempat, saling memaafkan antara satu pihak dengan pihak lainnya. Kelima, saya setuju bahwa tidak ada kontradiksi.

Dari 5 hal yang dinyatakan oleh George Simmel di atas as-as dapat dilihat bahwa hal yang dapat menyelesaikan konflik antara kedua belah pihak adalah selesainya konflik itu sendiri ditandai dengan kemenangan satu pihak ke pihak lain negosiasi rekonsiliasi dan juga saling memaafkan. Pada dasarnya untuk menyelesaikan konflik mengharuskan kedua belah pihak saling sepakat. Biasanya kesepakatan antara kedua belah pihak adalah kesepakatan yang yang tidak merugikan sebelah pihak ataupun keduanya. Kemudian kesepakatan yang diambil pastinya adalah kesepakatan yang saling menguntungkan keduanya ataupun tidak merugikan kedua belah pihak tersebut. Hal yang sulit dilakukan untuk menyelesaikan konflik adalah saling memaafkan antara satu pihak dengan pihak lainnya karena memang jika sudah terlanjur terjadi adanya konflik maka akan ada kemungkinan masih ada rasa dendam antara keduanya dengan membela masing-masing Kubu. Jika dilihat dari 5 hal di atas, maka yang paling logis dan masuk akal adalah kompromi atau negosiasi antara kedua belah pihak.

Pada dasarnya, setiap negara di dunia adalah multikultural. Keberadaan masyarakat multikultural menambah nilai bagi negara. Keberagaman ras, suku, suku, atau agama merupakan ciri khas tersendiri, karena negara Indonesia unik dan kompleks karena keragaman suku, agama, kebangsaan, dan ras. Masyarakat multikultural Indonesia adalah masyarakat yang berdasarkan multikulturalisme atau ideologi multikultural Bhineka Tunggal Ika dan melandasi ciri-ciri struktural masyarakat Indonesia pada tingkat nasional dan lokal.

Salah satu cara terbaik untuk merespon multikulturalisme dan menjalankannya dengan baik di Indonesia adalah dengan menjadikan sekolah-sekolah setingkat perguruan tinggi sebagai pusat sosialisasi dan penanaman nilai-nilai ambisius tersebut dengan melabelinya sebagai pendidikan multikultural. Inti dari multikulturalisme adalah toleransi, yang melayani kepentingan bersama dan menghormati kepercayaan dan interaksi dengan semua anggota masyarakat. Menumbuhkan sikap saling menghormati tanpa membedakan golongan seperti jenis kelamin, suku, ras, budaya, kelas sosial, atau agama. Ada beberapa pendekatan lain untuk proses pendidikan multikultural.

Begitu banyak konflik yang muncul, namun konflik membutuhkan solusi untuk saling memahami atau budaya satu daerah dan budaya lain. Bahkan jika ada solusi untuk mengatasi konflik, Anda tidak perlu terlalu khawatir tentang apa yang memicu antara individu dan individu, individu dan kelompok, kelompok dan kelompok, dan sebagainya. Orang lain adalah cara yang tepat untuk mencari bantuan dari orang lain ketika Anda membutuhkan bantuan. Jika Anda tidak ingin membantu, jangan memaksa orang lain untuk membantu untuk mencegah konflik di kemudian hari. 
Menurut Arifudin (2007: 2) ada beberapa pendekatan dalam proses pendidikan multikultural, antara lain: Pertama, pergeseran paradigma dalam memandang pendidikan dengan pendidikan sekolah atau pendidikan multikultural dengan program sekolah formal. Kedua, menghindari pandangan bahwa budaya disamakan dengan kelompok etnis. Artinya, budaya tidak harus diasosiasikan semata-mata dengan suku bangsa seperti yang terjadi di masa lalu. Ketiga, karena mengembangkan keterampilan dalam budaya baru biasanya memerlukan interaksi aktif dengan orang-orang yang sudah memiliki keterampilan, upaya mendukung sekolah yang beragam ras merupakan upaya dalam pendidikan multikultural, bahkan lebih jelas bertentangan dengan tujuan mereka. Keempat, pendidikan multikultural meningkatkan kapasitas dalam berbagai budaya. Budaya yang diadopsi tergantung pada keadaan. Kelima, pendidikan multikultural menumbuhkan kesadaran akan kemampuan multikultural baik di dalam maupun di luar sekolah.

Pendidikan multikultural di Indonesia lebih tepat dan cocok digunakan menjadi pendekatan yaitu pendekatan pendidikan yang mengupayakan supaya nilai-nilai budaya kedaerahan atau Suku bangsa dan kepercayaan pada Indonesia bisa dipahami dihargai dan dimanfaatkan buat kepentingan pendidikan kebangsaan dan jua kewarganegaraan berlandaskan slogan bineka Tunggal Ika dan falsafah Pancasila menggunakan mengedepankan toleransi \& kerukunan antar budaya \& pemeluk kepercayaan .

Pelaksanaan pendidikan multikultural tersebut dapat dilaksanakan secara bertahap melalui proses perancangan kurikulum hingga penyususnan rencana pelaksanaan pembelajaran. Setelah beberapa komponen yang diperlukan dalam pembelajaran direncanakan dengan baik, kemudian diaplikasikan dalam kegiatan belajar mengajar. Pendidikan multikultural tersebut dapat dijalankan melalui proses pembelajaran di lembaga pendidikan formal manapun, kegiatan ekstrakulikuler dan perilaku sehari hari. Untuk mencapai hasil yang maksimal, implementasi pendidikan multikultural ini juga harus didukung oleh lembaga pendidikan yang lainnya, yaitu pendidikan keluarga dan pendidikan dalam masyarakat.

Untuk mengimplementasi pendidikan multikultural dapat menggunakan beberapa pendekatan dalam proses penyelenggaraannya, yaitu pendekatan kontribusi, pendekatan aditif, pendekatan transformasi, dan pendekatan aksiisosial. Pendekatan tersebut diterapkan dengan cara mengintegrasikan nilai-nilai pendidikan multikultural dalam materi pembelajaran dan dalam kultur budaya sekolah. 


\section{KESIMPULAN}

Indonesia adalah negara yang sangat besar dengan keragaman budaya dari timur ke barat. Tidak dapat disangkal bahwa ada banyak perbedaan karena keragaman budaya Indonesia. Menyikapi perbedaan yang ada di Indonesia, prinsip-prinsip kehidupan berbangsa dan bernegara harus selalu dijunjung tinggi. Mediator atau media yang cocok untuk menyampaikan pembelajaran berupa nilainilai Pancasila, dan prinsip kehidupan berbangsa dan bernegara adalah pendidikan, khususnya pendidikan multikultural. Ada banyak jenis konflik multikultural di Indonesia: konflik individu, konflik sosial, konflik ras, konflik agama, konflik keluarga, dan konflik budaya. Georg Simmel menemukan bahwa ada cara lain untuk menyelesaikan konflik. Artinya, kemenangan satu pihak atas pihak lain, kompromi atau negosiasi antara pihak-pihak yang berperang, rekonsiliasi antara pihakpihak yang berperang, saling memaafkan dari satu pihak ke pihak lain, dan kesepakatan yang konsisten dengan dirinya sendiri. Pendidikan multikultural di Indonesia lebih tepat dan cocok digunakan menjadi pendekatan yaitu pendekatan pendidikan. Untuk mengimplementasi pendidikan multikultural dapat menggunakan beberapa pendekatan dalam proses penyelenggaraannya, yaitu pendekatan kontribusi, pendekatan aditif, pendekatan transformasi, dan pendekatan aksi sosial. Pendekatan tersebut diterapkan dengan cara mengintegrasikan nilai-nilai pendidikan multikultural dalam materi pembelajaran dan dalam kultur budaya sekolah.

\section{REFERENSI}

Al-Arifin, Akhmad Hidayatullah. (2012). Implementasi Pendidikan Multikulutral dalam Praksis Pendidikan di Indonesia. Jurnal Pembangunan Pendidikan: Fondasi dan Aplikasi 1.1.

Arifudin, Iis. (2007). Urgensi Implementasi Pendidikan Multikultural di Sekolah. Jurnal pemikiran alternatif pendidikan, |Vol. 12|No. 2|Mei-Ags 2007|220-233.

Baharun, Hasan \& Robiatul Awwaliyah. (2017). Pendidikan multikultral dalam menanggulangi narasi islamisme di Indonesia. Jurnal Pendidikan Agama Islam (Journal of Islamic Education Studies) Volume 5 Nomor 2.

Davis, Keith dan Newstrom, John W. ( Alih Bahasa: Dharma Agus ). (1993). Prilaku Dalam Organisasi, Jilid 1, Edisi Ketujuh, Cetakan Kedua, Penerbit Erlangga, Jakarta.

Dewantara, A. W. (2016). Gotong-royong Menurut Soekarno Dalam Perspektif Aksiologi Max Scheler, dan Sumbanganya Bagi Nasionalisme Indonesia. Doctoral dissertation, Universitas Gadjah Mada.

Dewantara, A. W. (2017). Multikulturalisme Indonesia (Studi Perbandingan Antara Konsep Madani Nurcholish Madji dan Konsep Civil Society). JPAK: Jurnal Pendidikan Agama Katolik, 17(9), 15-25. 
Ibrahim, Rustam. (2013). Pendidikan multikultural: Pengertian, Prinsip, dan Relevansinya dengan Tujuan Pendidikan Islam. Jurnal ADDIN, Vol. 7, No. 1, Februari 2013.

Khatibah, K. (2011). Penelitian kepustakaan. Iqra': Jurnal Perpustakaan dan Informasi, 5(01), 3639.

Mangkunegara, Anwar Prabu. (2005). Perilaku dan Budaya Organisasi. Bandung: Refika Aditama.

Mirshad, Z. (2014). Persamaam Model pemikiran al-Ghaza dan Abraham Maslow tentang model motivasi konsumsi. Surabaya: Tesis. UIN Suan Ampel Surabaya.

Muzaki, Iqbal Amar. (2018). Pendidikan Multikultural dalam Perspektif Islamic Worldview, Jurnal Penelitian Pendidikan Islam, Vol, 6, No. 1.

Nasikun. (2007). Sistem Sosial Indonesia. Jakarta: PT Grafindo Persada.

Rahman, Arif. ( 2019 ).Pendidikan Islam di Era Revolusi Industri 4.0. Komojoyo Press. Jl. Komojoyo 21 A, RT. 11, RW. 4 Mrican Kelurahan Caturtunggal. Kecamatan Depok Cetakan Pertama, Agustus.

Robbins, Stephen P.,(Alih Bahasa: Pujaatmaka, Hadyana). (1996). Prilaku Organisasi Konsep Kontroversi Aplikasi, Edisi Bahasa Indonesia, Jilid 2, PT. Prenhallindo, Jakarta.

Siswono, Agus. (2008). Kerusakan Lingkungan dan Konflik Sosial Nelayan di Kepulauan Karimunjawa. Majalah Ilmiah Psikologi Psikodimensia. Fakultas Psikologi Universitas Soegijapranata Semarang. Vol. 6 No. 2 Juli Desember 2007, ISSN: 1411-6073.

Sofyan. M. Soleh. (2009). Konflik da Integrasi Pada Masyarakat Majemuk. Yogyakarta: Lintang Pustaka Utama.

Sugiyono. (2018). Metode Penelitian Kuantitatif. Bandung: Alfabeta.

Suparlan, Parsudi. (2002). Menuju Masyarakat Indonesia yang Multikultural, Makalah. Disampaikan pada simposium Internasional Bali ke 3, Jurnal Antropologi Indonesia, Denpasar Bali, 16 - 21 Juli.

Yustisia. (2015). Akar Konflik Dalam Masyarakat Multikultral di Karimunjawa. Vol. 4 No. 3 September - Desember .

Zulkifli. (2020). Pendidikan Multikulturalisme sebagai Resolusi Konflik: Perspektif Pendidikan Kewarganegaraan, Jurnal Politik Hukum dan Kewarganegaraan, Volume 10 no 2 edisi September. 